\title{
Right Sided Optic Meningioma in a Young Girl
}

\author{
Neema Tiwari* \\ Department of Clinical Hematology, King George Medical University, India \\ *Corresponding author: Neema Tiwari, Department of Clinical Hematology, King George Medical University, India.
}

Submission: 㭰 December 13, 2017; Published: 眥 February 27, 2018

\section{Short Communication}

ONSMs are rare tumors of anterior visual pathway [1]. ONSMs arise from meningoepithelial cap cells of the arachnoids villi and can develop at any location along the entire course of the optic nerve sheath $[2,3]$. We received a case of right sided optic tumor completely involving the eyeball requiring exentration surgery and were sent to our department for analysis. On cut opening a firm whicte tumor surface was seen and on microscopy a diagnosis og meningothelial meningioma was made. The diagnosis was confirmed by EMA positivity.

OSNMs are of two types mainly Primary and secondary depending on their location. 40.8 years (42.5 years in women and 36.1 years in men; range 3-80 years), is the mean age of presentation for the lesion. The most common presentation is unilateral with females having highest presentation [4]. 5\% of ONSMs present bilaterally, and $65 \%$ of these bilateral lesions are intra canalicular [5]. Bilateral and multifocal presentations of ONSMs are most commonly found in patients with neurofibromatosis type 2 [6-8].

The pathogenesis of OSNMs is thought to be their compromise optic nerve function mainly by mass effect on the pial vasculature which induces ischemic changes as well as interferes with axonal transport in the nerve [9]. Patient may present with classic triad of visual loss, optic atrophy, and the presence of opticociliary shunt vessels on the disc [6]. Fundus examination reveals disc edema suggesting some manifestation of a compressive optic neuropathy or frank optic atrophy.

Once the diagnosis of an ONSM is suspected, the diagnosis can usually be established using MRI or high-resolution CT scan [4]. The characteristic features of ONSMs include the presence of calcification surrounding the nerve along with different radiographic growth patterns: Tubular, globular, fusiform, and focal.

Definitive treatment of ONSMs is related to its vascular supply. Surgical excision has almost always resulted in blindness in the affected eye. This could be due to excision of the tumor along with the affected optic nerve intra operatively or damage to the pial vasculature [10]. Conservative management is indicated if there is no significant progressive visual dysfunction, or intracranial extension of the tumor.

This commentary is important in the preview of OSNMs being a rare lesion which is seldom encountered and hence makes an interesting case discussion.

\section{References}

1. Saeed P, Rootman J, Nugent RA, White VA, Mackenzie IR (2003) Optic nerve sheath meningiomas. Ophthalmology 110(10): 2019-2030.

2. Turbin RE, Pokorny K (2004) Diagnosis and treatment of orbital optic nerve sheath meningioma. Cancer Control 11(5): 334-341.

3. Craig WM, Gogela LJ (1949) Intraorbital meningiomas; A clinicopathological study. Am J Ophthalmol 32(12): 1663-1680.

4. Dutton JJ (1993) Optic nerve sheath meningiomas. Surv Ophthalmol 37: 167-183.

5. Trobe JD, Glaser JS, Post JD, Page LK (1978) Bilateral optic canal meningiomas: A case report. Neurosurgery 3(1): 68-74.

6. Ortiz O, Schochet SS, Kotzan JM, Kostick D (1996) Radiologic-pathologic correlation: Meningioma of the optic nerve sheath. AJNR Am J Neuroradiol 17(5): 901-906.

7. Carrasco JR, Penne RB (2004) Optic nerve sheath meningiomas and advanced treatment options. Curr Opin Ophthalmol 15(5): 406-410.

8. Berman D, Miller NR (2006) New concepts in the management of optic nerve sheath meningiomas. Ann Acad Med Singapore 35(3): 168-174.

9. Miller NR (2002) The evolving management of optic nerve sheath meningiomas. Br J Ophthalmol 86(11): 1198.

10. Turbin RE, Thompson CR, Kennerdell JS, Cockerham KP, Kupersmith M] (2002) A long-term outcome comparison in patients with optic nerve sheath meningioma managed with observation, surgery, radiotherapy, or surgery and radiotherapy. Ophthalmol 109(5): 890-900. 
Creative Commons Attribution 4.0

International License

For possible submissions Click Here

\section{Your subsequent submission with Crimson Publishers} will attain the below benefits

- High-level peer review and editorial services

- Freely accessible online immediately upon publication

- Authors retain the copyright to their work

- Licensing it under a Creative Commons license

- Visibility through different online platforms

- Global attainment for your research

- Article availability in different formats (Pdf, E-pub, Full Text)

- Endless customer service

- Reasonable Membership services

- Reprints availability upon request

- One step article tracking system 